\title{
Correlation between Prolactin Serum with Neutrophil Lymphocyte Ratio (NLR) in Systemic Inflammatory Response Syndrome
}

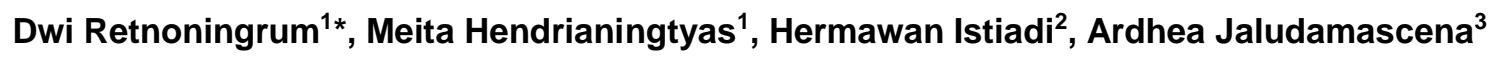

\author{
${ }^{1}$ Department of Clinical Pathology. Faculty of Medicine. Diponegoro University / \\ Diponegoro National Hospital, Indonesia \\ ${ }^{2}$ Department of Anatomical Pathology, Faculty of Medicine Diponegoro University, Indonesia \\ ${ }^{3}$ Department of Clinical Pathology, Dr. Kariadi Hospital, Indonesia
}

Keywords:

Neutrophil lymphocyte ratio

Prolactin

SIRS

*) Correspondence to: dwiretno@fk.undip.ac.id

Article history:

Received 28-11-2020

Accepted $08-12-2020$

Availableonline10-03-2021

\begin{abstract}
Background: Systemic inflammatory response syndrome (SIRS) is a state of systemic inflammatory activation by various causes. SIRS have a high mortality rate. Prolactin is known to regulate cellular function of immune system. Neutrophillymphocyte ratio (NLR) is simple, cost effective and easy parameter that currently used as inflammation marker.

Objective: The aims of this study is to determine the correlation between prolactin serum with NLR in SIRS patients.

Methods: A cross sectional study was conducted on 50 clinically SIRS patients. Prolactin serum was measured by enzyme linked immunosorbent assay (ELISA) and NLR was calculated manually from absolute neutrophil and lymphocyte count measured by automatic hematology analyzer. Non-parametric Spearman test was used to analyze the correlation between prolactin with NLR

Results: Median value of serum prolactin level was $11.32 \mathrm{ng} / \mathrm{mL}$ (2.76-194.81), whereas the mean value NLR was $16.36 \pm 11.58$. The correlation between prolactin levels with NLR was $\mathrm{r}=0.345, \mathrm{p}=0.014$.

Conclusion: There is a weak positive significant correlation between prolactin with neutrophil lymphocyte ratio in SIRS
\end{abstract}

DIMJ, 2021, 2(1), 10-13 DOI: https:// doi.org/10.14710/dimj.v2i1.9546

\section{Introduction}

Systemic inflammatory response syndrome (SIRS) state is systemic activation with multiple underlying causes. It has a high risk of sepsis and death $^{1}$. Septic patients are generally admitted to the ICU for long periods of up to 2-3 weeks. Antimicrobial agents and advanced life support have been used, but the case fatality rate of septic patients has been between 20-30\% over the past two decades. ${ }^{2}$ The incidence of sepsis in Europe is estimated to be $54-116$ cases in 100,000 populations per year. ${ }^{3}$ Systemic inflammatory response syndrome (SIRS) is characterized by two or more symptoms: body temperature $>38{ }^{\circ} \mathrm{C}$ or $<36{ }^{\circ} \mathrm{C}$; tachycardia $>90$ beats/minute; respiratory rate $>20$ breaths/ minute or $\mathrm{PaCO} 2<4.3 \mathrm{kPa}(32 \mathrm{mmHg})$; leukocyte count $>12,000 / \mathrm{mm} 3$ or $<4000 / \mathrm{mm} 3$ or $>10 \%$ immature neutrophils (band). ${ }^{1,2}$ The prevalence of SIRS is very high, covering one-third of total hospitalized patients and $>50 \%$ of intensive care unit (ICU) patients. In surgical ICU, SIRS can cover $>80 \%$ of patients. The prevalence of infection increases with the number of SIRS criteria met and the severity of the symptoms of sepsis increases. ${ }^{4}$

The state of SIRS or sepsis can affect Hypothalamic-Pituitary-Adrenal (HPA) axis associated with inflammation. Early release of cytokines from immune cells plays a role in body homeostasis by acting as paracrine, autocrine and endocrine with increased release of ACTH hormone (adrenocorticotropic hormone), growth hormone and prolactin hormone at the onset of $\operatorname{sepsis}^{5,6}$ Animal studies have shown that prolactin is associated with decreased survival and changes in the immune system. ${ }^{7}$ Prolactin plays a role in stimulating phagocytosis in several infectious microorganisms. 
In addition, prolactin also modulates leukocyte adhesion to the endothelium. ${ }^{8}$

The neutrophil-lymphocyte ratio (NLR) is an inexpensive and easy parameter of routine blood tests. Current use of NLR as a marker of inflammation has a good correlation with C-reactive protein (CRP). ${ }^{9}$ Holub et al (2012) concluded that an NLR with a cut-off of 6.2 has a sensitivity of $91 \%$ and a specificity of $96 \%$ for bacteremia patients. ${ }^{10} \mathrm{~A}$ study by Jager et al (2010) showed that NLR can be a predictor of bacteremia in emergency room patients. ${ }^{11}$

\section{Method}

The cross-sectional study was conducted in April-August 2016. The subjects were male, according to the SIRS criteria, age more than 18 years. Patients with autoimmune disease, domperidone and bromocriptine therapy were not included in this study. Serum prolactin hormone were examined by ELISA method. The reference value for male was $3-14.7 \mathrm{ng} / \mathrm{mL}$, NLR value was obtained from the absolute number of neutrophils divided by absolute number of lymphocytes obtained from the automatic haematology analyzer. Data were presented in the form of mean \pm standard deviation for numerical data with normal distribution, median (minimum-maximum) for abnormal distribution data. Data were analyzed using the Spearman correlation test to determine the correlation between serum prolactin level and NLR.

\section{Results}

Fifty (50) subjects were included in this study. The research characteristics can be seen in table 1 . The data normality test results of NLR obtained normal distribution, but the prolactin result were not normal distribution so that the correlation test is done using Spearman Correlation test. The results of the Spearman correlation test analysis showed that there was a weak correlation between prolactin with NLR $(\mathrm{r}=0.345, \mathrm{p}=0.014)$. (Fig. 1$)$

Tabel 1. Baseline characteristics in subjects

\begin{tabular}{lccc}
\hline \multicolumn{1}{c}{ Parameter } & Mean $\pm \mathrm{SD}$ & Median $($ min-max $)$ & $\mathrm{p}^{*}$ \\
\hline Age $($ years $)$ & $49.9 \pm 13.9$ & $55.5(18-77)$ & 0.00 \\
Hemoglobin $(\mathrm{mg} / \mathrm{dL})$ & $12.4 \pm 2.3$ & $12.8(7.4-16.3)$ & 0.20 \\
Leukocyte count $(/ \mu \mathrm{L})$ & $16,965 \pm 6,749$ & $16,150(3,100-38,500)$ & 0.01 \\
Neutrophil $(/ \mu \mathrm{L})$ & $14,635 \pm 6,238$ & $13,800(2,490-35,000)$ & 0.06 \\
Lymphocyte $(/ \mu \mathrm{L})$ & $1,287 \pm 799$ & $985(200-3,300)$ & 0.01 \\
Platelet $(/ \mu \mathrm{L})$ & $253,362 \pm 109,280$ & $239,500(84,400-617,000)$ & 0.20 \\
NLR & $16.37 \pm 11.58$ & $14.8(1.5-54.46)$ & 0.11 \\
Prolactin $(\mathrm{ng} / \mathrm{mL})$ & $25.77 \pm 38.6$ & $11.32(2.76-194.81)$ & 0.00 \\
\hline
\end{tabular}

$* \mathrm{p}=$ Kolmogorov Smirnov

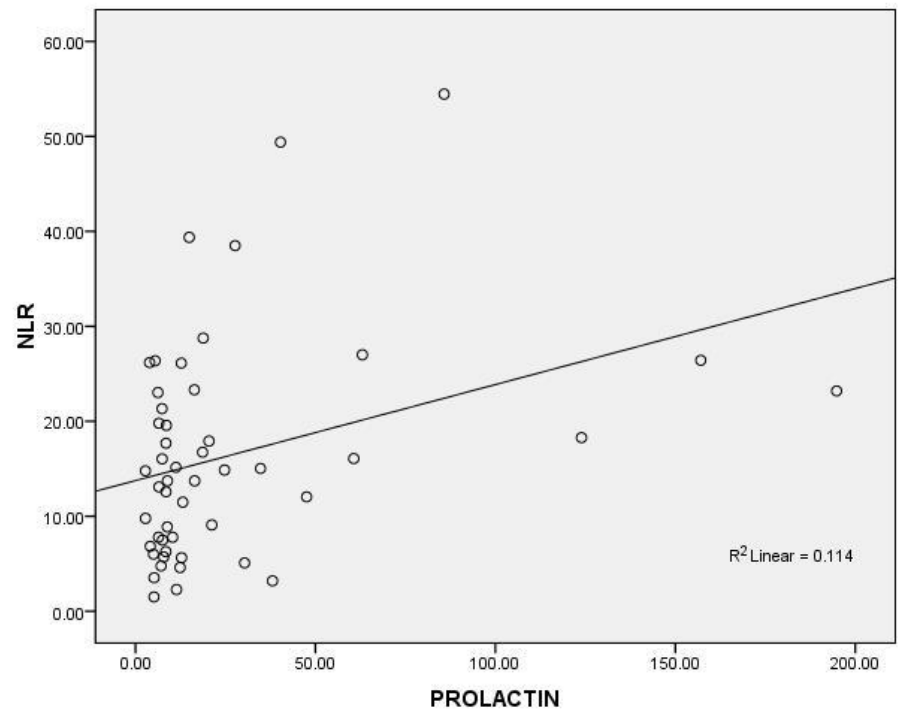

Figure 1. Scatter plot of the correlation between serum prolactin and NLR 


\section{Discussion}

The mean age of the subjects of this study was $49.9 \pm 13.85$ years, with an age range between 18-77 years, median value of 55.5 years, these results are in accordance with the study of Kofoed et al. with median age was 56 year (range 20-94 years). ${ }^{12}$ According to the study of Comstedt et al, SIRS occurred at the age of 15-96 years, whereas Lai et al, SIRS occurred at a mean age of $62 \pm 17$ years. ${ }^{13,14}$ The results of the Spearman correlation test analysis showed that there was a weak correlation between serum prolactin levels and NLR $(\mathrm{r}=0.345, \mathrm{p}=$ 0.014). Study of Tuyan et al., reported a correlation between NLR and prolactin levels in infertility patients $(\mathrm{r}=0.409, \mathrm{p}=0.043) .{ }^{15}$

The main biological function of prolactin hormone known so far is a lactation hormone. Some evidence suggests that the prolactin hormone is a growth factor for lymphocyte and stimulates an immune response. Prolactin is also produced by immune system cells, such as macrophages, NK cells, T lymphocytes and B lymphocytes. In addition, almost all hematopoietic cells have prolactin receptors on their cell surface. ${ }^{16,17}$ Increased levels of the prolactin hormone can cause changes in the state of immunity in pathological conditions. Hyperprolactinemia has been reported to occur in several autoimmune diseases such as systemic lupus erythematosus (SLE), rheumatoid arthritis, and systemic sclerosis. The effect of the prolactin hormone on pancreatic beta cells, liver, $\mathrm{T}$ lymphocytes is to regulate cell proliferation, while in the prostate, lymphocytes, ovarian carcinoma cells, breast carcinoma cells and others, prolactin acts as an anti-apoptosis factor. ${ }^{16,18,19}$ Prolactin regulates the functions of proliferation, differentiation, angiogenesis and protection from apoptosis and inflammation. The action of prolactin begins with binding to specific membrane receptors, where prolactin receptors are present in immune cells and are included in cytokine receptors such as IL-2, IL-3, IL-4, IL-6, IL-7 receptors, growth hormone and erythropoietin. ${ }^{15}$ Prolactin acts as a pro-inflammatory cytokine by increasing the production of IFN-c, IL12 , and IL-1b in peritoneal macrophages ${ }^{20}$ Prolactin also increase the production of IFN-c and TNF- $\alpha$ in $\mathrm{T}$ cells and mononuclear cells. ${ }^{21}$

During inflammatory conditions prolactin has been described as inducing phagocytosis, although the mechanism by which prolactin regulates phagocytosis is unknown and induces release of proinflammatory cytokines. Immunomodulation of prolactin appears to be an increase in transcription factors such as IRF and NF- $\kappa \mathrm{B}$ which play a role in immune function. ${ }^{22}$ Brand et al (2004), have shown that prolactin increases the release of TNF- $\alpha$ and IL2 from mononuclear cells by stimulation of LPS (lipopolysaccharide). TNF- $\alpha$ and IL-2 are important cytokines as mediators of inflammation, complications of sepsis and autoimmunity. ${ }^{23}$

There were several limitations of this study. This study did not exclude the presence of psychological stress that can increase prolactin levels. This study also did not measure the pro-inflammatory cytokines that play a role in the pathophysiology of SIRS.

\section{Conclusion}

There is a weak positive significant correlation between prolactin with neutrophil lymphocyte ratio in systemic inflammatory response syndrome.

\section{Ethical Approval}

This research was conducted upon approval from the Health Research Ethics Commission (KEPK) of the Faculty of Medicine of Diponegoro University/RSUP Dr. Kariadi Semarang with the number of 726/EC/FK-RSDK/VI/2016, issued on June 24, 2016.

\section{Conflicts of Interest}

The authors declare no conflict of interest.

\section{Funding}

This research is supported by the Ministry of Research Technology and Higher Education of Indonesia.

\section{References}

1. Horeczko T, Green JP, Panacek EA. Epidemiology of the Systemic Inflammatory Response Syndrome ( SIRS ) in the Emergency Department. West J Emerg Med. 2014;15(3):329-36.

2. Marik PE. Surviving sepsis: going beyond the guidelines. Ann Intensive Care. 2011;1(1):17.

3. Rezende E, Silva JM, Isola AM, Campos EV, Amendola CP, Almeida SL. Epidemiology of severe sepsis in the emergency department and difficulties in the initial assistance. Clinics (Sao Paulo). 2008;63:457-64.

4. Leksana E. Systemic Inflammatory Response Syndrome. Cermin Dunia Kedokt. 2013;40(1):7-11.

5. Kanczkowski W, Alexaki V-I, Tran N, Großklaus S, Zacharowski K, Martinez A, et al. 
Hypothalamo-pituitary and immune-dependent adrenal regulation during systemic inflammation. Proc Natl Acad Sci U S A. 2013;110(36):14801-6.

6. Vardas K, Apostolou K, Briassouli E, Goukos D, Psarra K, Botoula E, et al. Early Response Roles for Prolaktin Cortisol and Circulating and Cellular Levels of Heat Shock Proteins 72 and 90 in Severe Sepsis and SIRS. Biomed Res Int. 2014;2014.

7. Oberbeck R, Schmitz D, Wilsenack K, Schu M, Biskup C, Schedlowski M, et al. Prolaktin Modulates Survival and Cellular Immune Functions in Septic Mice 1. J Surg Res. 2003;256:248-56.

8. López-meza JE, Lara-zárate L, Ochoa-zarzosa A. Effects of Prolaktin on Innate Immunity of Infectious Diseases. Open Neuroendocrinol J. 2010;3:175-9.

9. Lou M, Luo P, Tang R, Peng Y, Yu S, Huang $\mathrm{W}$, et al. Relationship between neutrophillymphocyte ratio and insulin resistance in newly diagnosed type 2 diabetes mellitus patients. BMC Endocr Disord. 2015;15:4-9.

10. Holub M, Beran O, Kasprííková N, Chalupa P. Neutrophil to lymphocyte count ratio as a biomarker of bacterial infections. Cent Eur $\mathbf{J}$ Med. 2012;7(2):258-61.

11. de Jager CPC, van Wijk PTL, Mathoera RB, de Jongh-Leuvenink J, van der Poll T, Wever PC. Lymphocytopenia and neutrophil-lymphocyte count ratio predict bacteremia better than conventional infection markers in an emergency care unit. Crit Care. 2010;14(5).

12. Kofoed K, Eugen-Olsen J, Petersen J, Larsen K, Andersen O. Predicting mortality in patients with systemic inflammatory response syndrome: an evaluation of two prognostic models, two soluble receptors, and a macrophage migration inhibitory faktor. Eur J Clin Microbiol Infect Dis. 2008;27(June):375-83.

13. Comstedt P, Storgaard M, Lassen AT. The Systemic Inflammatory Response Syndrome (SIRS) in acutely hospitalised medical patients: a cohort study. Scand J Trauma Resusc Emerg Med. 2009;17:67.
14. Lai NA, Kruger P. The predictive ability of a weighted systemic inflammatory response syndrome score for microbiologically confirmed infection in hospitalised patients with suspected sepsis. Crit Care Resusc. 2011;14(3):146-50.

15. Tuyan T, Gazi M, Celik C, Hilmi S. Relationship Between Prolaktin Levels and Neutrophil / Lymphocyte Ratio in Patients With Unexplained Infertility. Med J Aegean Clin. 2015;53(3):140 5.

16. Freeman ME, Kanyicska LA, Lerant A, Nagy G. Prolaktin : Structure, Function, and Regulation of Secretion. 2000;80(4):1523-631.

17. Buckley A. Prolaktin, a lymphocyte growth and survival faktor. Lupus. 2001;10:684-90.

18. Díaz L, Díaz-muñoz M, González L, Liraalbarrán S, Larrea F, Méndez I. Prolaktin in the Immune System. In: Prolaktin. Croatia: Intech; 2013. p. 53-82.

19. Bellis A, Bizzarro A, Pivonello R, Lombardi G, Bellastella A. Prolaktin and Autoimmunity. Pituitary. 2005;8:25-30.

20. Sodhi A, Tripathi A. Prolaktin and growth hormone induce differential cytokine and chemokine profile in murine peritoneal macrophages in vitro: Involvement of p-38 MAP kinase, STAT3 and NF- $\kappa$ B. Cytokine. 2008;41(2):162-73.

21. Matera L, Mori M. Cooperation of pituitary hormone prolaktin with interleukin-2 and interleukin-12 on production of interferongamma by natural killer and $\mathrm{T}$ cells. [Internet]. Vol. 917, Annals of the New York Academy of Sciences. 2000. p. 505-13. Available from: http://www.ncbi.nlm.nih.gov/pubmed/1126837 8

22. López-meza JE, Lara-zárate L, Ochoa-zarzosa A. Effects of Prolaktin on Innate Immunity of Infectious Diseases. 2010;175-9.

23. Brand JM, Frohn C, Cziupka K, Brockmann C, Kirchner H, Luhm J. Prolaktin triggers proinflammatory immune responses in peripheral immune cells. Eur Cytokine Netw. 2004;15(2):99-104. 